\title{
COMPARING LIVING AND HOLOCENE COCCOLITHOPHORE ASSEMBLAGES IN THE AEGEAN MARINE ENVIRONMENTS
}

\author{
Dimiza M. D. ${ }^{1}$ and Triantaphyllou M. V. ${ }^{1}$ \\ ${ }^{1}$ Department of Historical Geology and Palaeontology, Faculty of Geology and Geoenvironment, \\ University of Athens, Panepistimiopolis 15784,Athens, Greece,mdimiza@geol.uoa.gr,mtriant@geol.uoa.gr
}

\begin{abstract}
Detailed quantitative analyses of coccolithophores performed on the shallow deposits of the southeastern Aegean region (core NS-14, $505 \mathrm{~m}$ depth), evidenced that the distribution of calcare-ous nannoplankton assemblages during the last $13 \mathrm{ka} \mathrm{BP}$ reflects paleoenvironmental changes which are directly related to parameters such as temperature, salinity, productivity and nutrient flux in the water column. Analysis enabled the separation of the assemblages in four groups. Group A consists of Emiliania huxleyi and the subtropical species Syracosphaera spp. and Rhabdosphaera clavigera, Group B is composed of Helicospaera spp. and Florisphaera profunda, typical species for high productivity conditions in the middle-lower photic zone, Group C consists of Gephyrocapsa oceanica and Braarudosphaera bigelowii, that characterise low salinity conditions and Group D includes Umbilicosphaera spp. and Calcidiscus spp. which are described as relatively eutrophic species. The Holocene assemblages differ distinctly from the living coccolithophore communities in the coastal ecosystems of the Aegean Sea, where only Group A coccolithophores are thriving in the seasonally controlled marine environment.
\end{abstract}

Key words: coccolithophores, living communities, fossil assemblages, Holocene, Aegean Sea.

\section{Introduction}

Coccolithophores/calcareous nannoplankton constitute a significant component of the marine phytoplankton in modern oceans that can provide sensitive indicators of environmental conditions because it directly depends on surface water temperature, salinity, nutrient contents, and the availability of sunlight (e.g. Giraudeau et al., 1993; Winter et al., 1994). Consequently, changes in fossil coccolithophore assemblages, recorded by the study of marine sediments, are a successful palaeontological tool for the reconstruction of the paleoclimatic and paleoceanographic conditions in the geological past (e.g. Negri and Giunta, 2001; Principato et al., 2006; Giunta et al., 2003, Triantaphyllou et al., 2009a). In the Mediterranean Sea waters, the living coccolithophores present a high number of species (e.g. Kleijne, 1993; Cros, 2001; Knappertsbusch, 1993; Triantaphyllou et al., 2002, 2004; Malinverno et al., 2003; Dimiza et al., 2008a) with a strong seasonal variability and regional patchiness. The oligotrophic character of the Mediterranean Sea, as well as the high seasonality in sea surface temperatures, solar radiation, nutrient concentrations and in the circulation of surface water masses affect the content, the species abundance and the productivity of living coccolithophores in general. In addition, the region is ideal for reconstructions of past climatic changes due to its unique physical and geographic configuration, as it displays complicate sea-bed morphology and numerous island complexes. The short- and long- time 


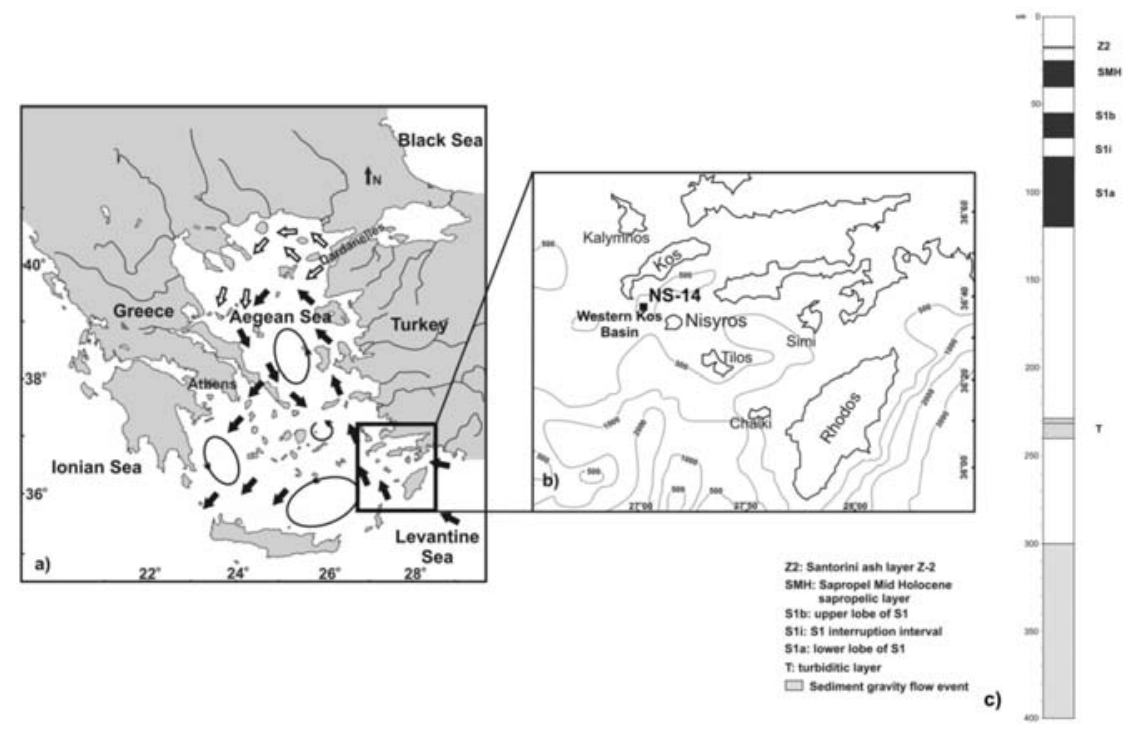

Fig. 1: a Location of the study area in the SE Aegean Sea and principal circulation patterns of the surface waters. b Location of core NS-14. c Core NS-14 stratigraphy (after Triantaphyllou et al., 2007, 2009a, b).

scale climatic and oceanographic events of the Late Glacial - Holocene, as recorded in the sediment record, resulted in the response of coccolithophores and was therefore recorded in fossil assemblages. We attempt herein to determine the changes in calcareous nannoplankton assemblages of the southeastern Aegean region (core NS-14) during the last $13 \mathrm{ka} \mathrm{BP}$. Diversity indices and multivariate analyses were used in order to evaluate the impact of environmental changes on fossil coccolithophore assemblages using the ecological preferences of several taxa. Moreover, a comparison of the fossil coccolithophore assemblages with the living coccolithophore communities in the Aegean Sea is provided.

\section{Materials and previous studies}

The NS-14 gravity core, $400 \mathrm{~cm}$ long was recovered during the R/V Aegeo-Cruise 1998, in western Kos Basin (SE Aegean Sea), from a water depth of $505 \mathrm{~m}$, at $36^{\circ} 38^{\prime} 55^{\prime \prime} \mathrm{N}$ and $27^{\circ} 00^{\prime} 28^{\prime \prime} \mathrm{E}$ (Fig. 1a, b). The western Kos Basin lying between Kos and Nisyros islands represents the easternmost edge of the volcanic arc that characterizes the recent Aegean Sea. The prominent tectonic features of the area are dominated by the active Kos fault zone, resulting to the complexity of the bottom morphology and the existence of five separate submarine basins including the western Kos basin. The depth of the basin does not exceed $510 \mathrm{~m}$ (Papanikolaou and Nomikou, 2001).

The dominant lithology of the sediment core is grey hemipelagic mud (Fig. 1c). The most recent Z2 Santorini tephra layer is positioned at a depth of $17 \mathrm{~cm}$. A first dark layer, defined as the midHolocene sapropel-like layer (Sapropel Mid Holocene -SMH; Triantaphyllou et al., 2009b). Sapropel $\mathrm{S} 1$ is recognised from 55 to $120 \mathrm{~cm}$ and is distinctively divided in two units (S1a, S1b) by a lighter grey coloured interval from $69-80 \mathrm{~cm}$. A turbiditic layer (T) is located between 231 and 240 $\mathrm{cm}$. Grey clay with pebbles prevail from $300 \mathrm{~cm}$ to the bottom, representing a gravity flow event (Triantaphyllou et al., 2009a, b). 
The age model for core NS-14 has been taken from Triantaphyllou et al. (2009b). According to the age model the base of S1a is considered to have an age of $10 \mathrm{ka}$ cal BP whereas the top of S1a corresponds to $7.9 \mathrm{ka}$ cal $\mathrm{BP}$. The top of $\mathrm{S} 1$ interruption is calibrated at $7.3 \mathrm{ka} \mathrm{cal} \mathrm{BP}$ and the top of $\mathrm{S} 1 \mathrm{~b}$ has an age of $6.4 \mathrm{ka}$ cal BP.

\section{Methodology}

A total of 156 samples were collected for coccolithophore analysis every $2 \mathrm{~cm}$ in the hemipelagic mud and every $1 \mathrm{~cm}$ in the sapropel intervals from the upper $300 \mathrm{~cm}$ of the NS-14 gravity core. Sample preparation followed standard smear slide techniques. Analyses were performed using a Leica DMSP optical polarising light microscope at 1250x magnification by counting at least 300 specimens per sample. Additional counts of 15 fields of view (Negri and Giunta, 2001) were performed for the species lesser occurrence such as Helicosphaera spp., Rhabdosphaera clavigera, Syracosphaera spp. The rare species Braarudosphaera bigelowii was counted in a fixed area of 150 fields of view. All results were converted in relative abundances of selected species in order to avoid dilution effects such as the input of terrigenous matter (Flores et al., 1997).

The ecological measures were calculated using the Past.exe 1.23 software package (Hammer et al., 2001), including Dominance (D) and Shannon-Wiener $\left(\mathrm{H}^{\prime}\right)$ diversity indices. The dominance index (Simpson, 1949) was calculated to express the abundance of the most common taxa as a fraction of the total number of individuals, whereas Shannon Wiener index measures heterogeneity evaluation, which means the distribution of individuals in the different taxa (Magurran, 1988).

Multivariate statistical analyses [R-mode Principal Component Analysis (PCA) and Hierarchical Cluster Analysis (HCA)] were performed using SPSS (version 10.1) statistical software. Analyses applied to 10 taxa with sufficient occurrence and higher abundance. HCA was used to determine species associations and to assess the ecological affinity among different groups. PCA was carried out in order to evaluate the factors that interpreted the impact of environmental changes on fossil coccolithophore assemblages.

\section{Results}

R-mode HCA on nannoflora of the core NS-14 allowed us to discriminate four groups of coccolithophore taxa (Fig. 2). In Group A Emiliania huxleyi is the most abundant species. Associated taxa include Rhabdosphaera clavigera and Syracosphaera spp. (mainly S. pulchra). Group B is dominated by Florisphaera profunda and Helicospaera spp. (mainly H. carteri). The Group C consists of Gephyrocapsa oceanica and Braarudosphaera bigelowii and Group D is composed of Umbilicosphaera spp. and Calcidiscus spp.

In addition, R-mode PCA allows an interpretation of the complex patterns of nannofossil changes on the Holocene deposits of the southeastern Aegean region. The first and second components of PCA account for $29 \%$ and $25 \%$ of the variance respectively. The first component is positively loaded mainly by E. huxleyi with negative loadings for F. profunda, while the second component is positively loaded mainly by Umbilicosphaera spp. and G. oceanica (Table 1).

The cumulative plots of the four coccolithophore Groups are shown in figure 3. They are plotted with the pattern of diversity indices and score plots of two components of PCA. Group A characterizes the lower part of core (> $10.5 \mathrm{ka} \mathrm{cal} \mathrm{BP})$. Above this, its relative abundance gradual decreases with minimum frequencies (exceeds $40 \%$ ) between 76-72 ka cal BP. Group A increases again from $\sim 4.5$ $\mathrm{ka}$ cal BP towards the core top. At the mid-section of the core, between 10.5 and $6.7 \mathrm{ka}$ cal BP, 


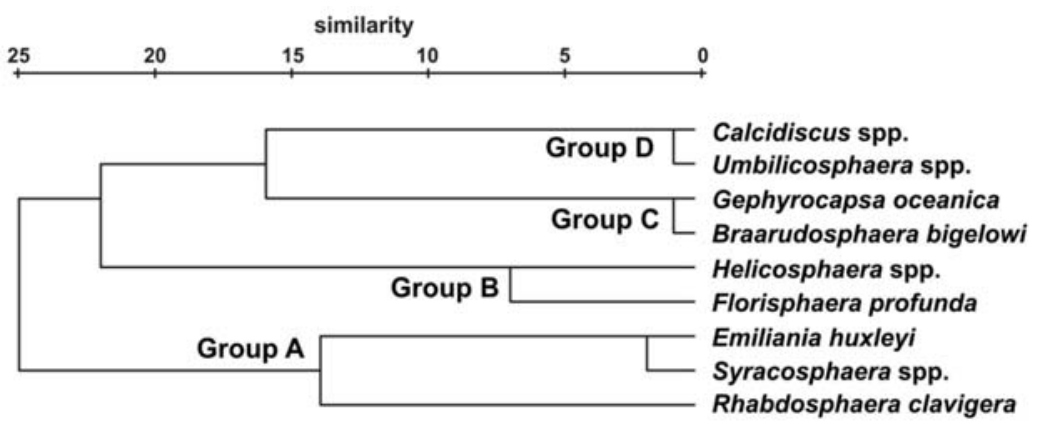

Fig. 2: HCA (centroid linkage method; distance metric is 1-Pearson correlation coefficient) based on the relative abundance of the coccolithophore species.

Group B alternates with Group A and presents maximum frequencies (up to $60 \%$ ) between 7.6 and $7.2 \mathrm{ka}$ cal BP. The presence of Group $\mathrm{C}$ is distinct in the upper part of core after $8 \mathrm{ka}$ cal BP, while Group D occurs mainly between 6.5 and $4.8 \mathrm{ka}$ cal BP with an abrupt increase at $\sim 6.5 \mathrm{ka}$ cal BP.

The components singled out by the PCA may be referred to Groups of the HCA. The component 1 score plot shows similar graphic trend with Group A and opposite with Group 2 (Fig. 3). The component 2 score plot present short fluctuations and mainly negative values at the lower part of core

Table1. Component Matrix

\begin{tabular}{|c|c|c|}
\hline & component 1 & component 2 \\
\hline Braarudosphaera bigelowii & 0,090 & 0,661 \\
\hline Calcidiscus spp. & 0,124 & 0,651 \\
\hline Emiliania huxleyi & 0,947 & 0,033 \\
\hline Florisphaera profunda & $-0,939$ & $-0,115$ \\
\hline Gephyrocapsa oceanica & 0,146 & 0,700 \\
\hline Helicosphaera spp. & $-0,407$ & 0,472 \\
\hline Rhabdosphaera clavigera & 0,313 & $-0,026$ \\
\hline Syracosphaera spp. & 0,658 & 0,076 \\
\hline Umbilicosphaera spp. & $-0,245$ & 0,819 \\
\hline
\end{tabular}

(> 8 ka cal BP), while significantly more positive values are observed between 6.5 and $4.8 \mathrm{ka}$ cal BP. A general increase in Shannon-Wiener index across the core is observed, with three abrupt drops between 7.5 and $7.2 \mathrm{ka} \mathrm{cal} \mathrm{BP}$, at $5.5 \mathrm{ka}$ cal BP, and from $3.8 \mathrm{ka}$ cal BP to towards the core top (Fig. 3). On the contrary, Dominance index exhibits abrupt raises between 7.7 and $7.2 \mathrm{ka}$ cal BP, 6.6-6.2 $\mathrm{ka}$ cal BP and 5.8-5.3 ka cal BP and 3.6-3.3 ka cal BP. In general, the Dominance index presents a relative opposite trend in the respect to the Shannon-Wiener index and positive correlation with the Group A ( $r=0.67)$, therefore a rising of Group A corresponding to increase in dominance. 

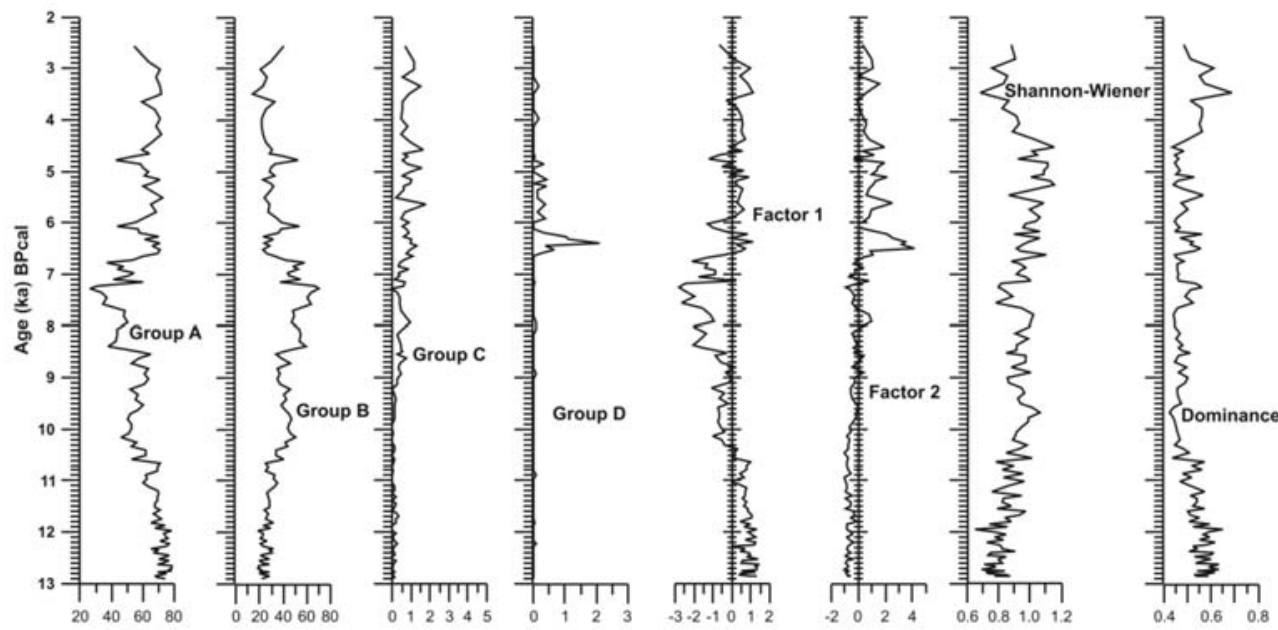

Fig. 3: Cumulative plots of the four coccolithophore Groups, score plots of two components of PCA and pattern of diversity indices.

\section{Holocene coccolithophore assemblages: Paleoecological groups}

In order to interpret the quantitative results, we discuss the ecological behaviour of coccolithophore species and paleoecological meaning for each of the four groups of the HCA. Syntheses of ecological data on coccolithophores show that certain associations of species characterize different environmental conditions.

Group A consists of the subtropical species Syracosphaera spp. R. clavigera and the opportunistic E. huxleyi. E. huxleyi is by far the most abundant of the coccolithophores on a global basis and has a wide ecological distribution. In the Mediterranean Sea waters, this species prevails throughout the year in the living coccolithophore assemblages (Knappertsbusch, 1993; Kleijne, 1993; Cros, 2001; Triantaphyllou et al., 2002, 2004; Malinverno et al., 2003), and predominates during winter in the Aegean Sea (Dimiza et al., 2008a). R. clavigera is warm water species of the upper water column (Roth and Coulbourn, 1982; Brand, 1994; Haidar and Thierstein, 2001; Malinverno et al., 2003). This species is abundant in the Mediterranean Sea waters (Kleijne, 1993; Malinverno et al., 2003; Dimiza et al., 2008a). R. clavigera is considered oligotrophic species (Jordan and Winter, 2000; Haidar and Thierstein, 2001) and according to Brand (1994), grows well at low nutrient levels and does not increase its growth rate in response to elevate nutrient concentrations. Syracosphaera is the most diverse living coccolithophore genus (Jordan and Chamberlein, 1997). Young (1994) included Rhabdosphaeraceae along with Syracosphaeraceae and holococcolithophores in the "miscellaneous" group of species; this group does not have an obviously distinctive biogeography, but tends to be more important in intermediate environments than in the extreme eutrophic or oligotrophic conditions, showing a tendency towards weak K-selection/efficiency maximizing (Brand, 1994; Young, 1994; Baumann et al., 2005). In the eastern Mediterranean Sea waters, Syracosphaera is a significant component of coccolithophore nannoflora and is represented mainly by $S$.pulchra, S. histrica, S. molischii, S. ossa, and S. halldalii (Dimiza et al., 2008a). In this study, the genus Syracosphaera is represented mainly by $S$. pulchra, a typical species of tropical-subtropical oligotrophic environments (Roth and Coulbourn, 1982; Findlay and Giraudeau, 2000; Haidar and Thierstein, 2001; Ziveri et al., 2004). 
Group B is composed of $H$. carteri and $F$. profunda typical species for high productivity conditions in the middle-lower photic zone. F. profunda is included in the floriform coccolithophores which live below the thermocline under low light and temperature conditions (Young, 1994; Winter et al., 1994; Takahashi and Okada, 2000; Malinverno et al., 2003; Dimiza et al., 2008b). This species has proven to be a very reliable proxy to locate the nutricline-thermocline level in tropical and subtropical environments (Molfino and McIntyre, 1990) and is important in paleoenvironmental reconstructions (Castradori, 1993; Beaufort et al., 1997; Di Stefano and Incarbona, 2004). In recent Eastern Mediterranean - as it has been confirmed by sediment trap data - the relative abundance of $F$. profunda is more intense during the low coccolithophore productivity interval when max sea surface temperature is occurring (Triantaphyllou et al., 2004) pointing to a deeper nutricline according to the model of Molfino and McIntyre (1990) and supporting Ahagon et al. (1993) who recognized a close relationship between the increase of $F$. profunda and increased water transparency. Helicosphaera spp. is known to preferentially high productivity waters in the middle photic zone (Ziveri et al., 2004; Crudeli et al., 2006). In this study, the genus Helicosphaera is represented mainly by H. carteri, a species with preference in warm waters (Brand, 1994; Baumann et al., 2005) and moderately elevated nutrient levels (Findlay and Giraudeau, 2000; Andruleit and Rogalla, 2002; Ziveri et al., 2004). According to Cros (2001) in the western Mediterranean Sea waters, this species lives close to the chlorophyll maximum.

Group C consists of G. oceanica and B. bigelowi that characterise low salinity conditions. G. oceanica prefers warm, high-nutrient, less saline environments (Roth and Coulbourn, 1982; Klejine, 1993; Knappertsbusch, 1993; Jordan and Winter, 2000; Takahashi and Okada, 2000; Andruleit and Rogalla, 2002; Di Stefano and Incarbona, 2004), such as upwelling areas or continental shelves (Giraudeau, 1992; Young, 1994). B. bigelowii is known to preferentially low salinity saline surface waters (Müller, 1979; Negri and Giunta, 2001; Giunta et al., 2003).

Group D includes Umbilicosphaera spp. and Calcidiscus spp. which are described as relatively eutrophic species. Umbilicosphaera spp. are warm water taxa (Flores et al., 1999; Takahashi and Okada, 2000) with a preferential in high-nutrient environments (Roth and Coulbourn, 1982; Young, 1994; Andruleit and Rogalla, 2002) and is consistent with the nutrient redistribution in the surface waters (Principato et al., 2006). According to Shipe et al. (2002), it presents positive correlation with decline of salinity. Calcidiscus spp. is considered by several authors as being characteristic of tropical to subtropical oligotrophic warm waters (Klejine, 1993; Winter et al., 1994; Flores et al., 1999; Baumann et al., 2004). However, some ecological preference for cold eutrophic environments have been inferred (Giraudeau, 1992; Young, 1994; Flores et al., 1997, Hiramatsu and De Deckker, 1997; Andruleit and Rogalla, 2002).

\section{Comparison between living and Holocene assemblages}

According to the results of the HCA, it was possible to identify the succession of four distinct groups, in the Aegean coccolithophore assemblages during the last $13 \mathrm{ka}$ : Group A (subtropical species- $R$. clavigera and Syracosphaera spp. and the opportunistic E. huxleyi), Group B (high productivity species-F. profunda and Helicosphaera spp.), Group C (low salinity species-G. oceanica and B. bigelowii) and Group D (relative eutrophic species-Calcidiscus spp. and Umbilicosphaera spp.). By applying the PCA, two important statistical factors interpreted the impact of environmental changes on calcareous nannoplankton distribution. The first component represents productivity variation, while the second component reflects high nutrient and low salinity conditions. Moreover, the Shannon diversity shows an opposite trend with regard to the Dominance index. The positive correlation 


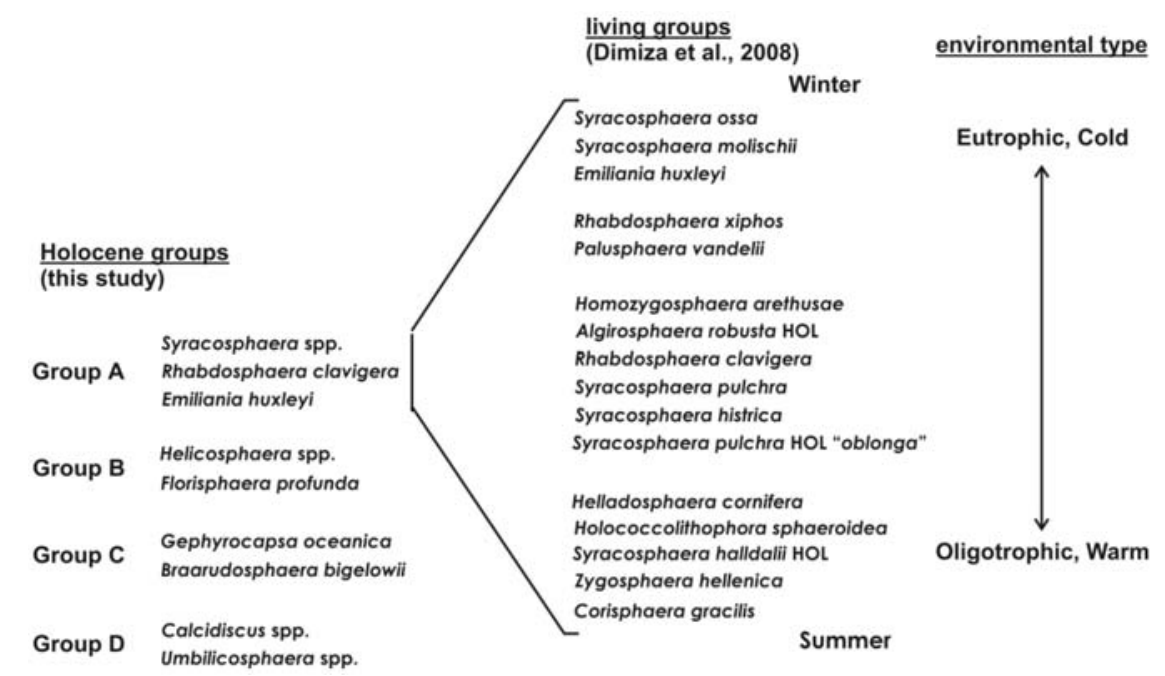

Fig. 4: Correlation between Holocene and living coccolithophore assemblages.

between dominance and Group A is interpreted with predominance of r-selected species E. huxleyi of Group A in eutrophic conditions (Young, 1994). Consequently, the fluctuation in the environmental conditions of the Holocene, in the eastern Mediterranean region, which is directly related to parameters such as temperature, salinity, productivity and nutrient flux in the water column, is ideally reflected in the coccolithophore assemblages.

In the study of living coccolithophore communities from the coastal ecosystems of Andros Island, Dimiza et al. (2008a) identified four distinct recent coccolithophore groups in the upper water column: Emiliania huxleyi group (late autumn-early spring), Palusphaera vandelii group (spring), Rhabdosphaera clavigera group (summer), Helladosphaera cornifera group (early autumn), suggesting that variability in coccolithophore composition in the Aegean Sea is controlled by the oligotrophic and warm summer and eutrophic and cold winter seasonal cycle. As the Aegean region today appears to be one of the most oligotrophic areas in the world, the research on extant coccolithophores from the coastal ecosystems provided detailed results concerning the expansion of the species of subtropical-oligotrophic environments.

Comparing the determined Holocene and living coccolithophore groups it becomes obvious that the latter are exclusively dominated by the subtropical species $R$. clavigera and Syracosphaera spp. and the opportunistic E. huxleyi, which correspond to the paleoecological Group A (Fig. 4). In particular the living ecological groups that were identified are based on E. huxleyi and various species of families Rhabdosphaeraceae, Syracosphaeraceae and Calyptrosphaeraceae. The latter include holococcoliths that are rarely preserved in sediments and are therefore not easily included in paleontological assemblages.

The species composition of fossil assemblages is influenced from sedimentological and preservational processes. Recent detailed study of sinking planktonic assemblages and Holocene samples (Andruleit et al. 2004; Baumann et al., 2005; Young et al., 2005) indicates that the majority of the morphological diversity is dissolved in the upper water column. In surface waters, delicate forms (species of several different groups of coccolithophores, including the Rhabdosphaeraceae and almost all holococcolithophores) present low preservation potential and preferential destroyed (Roth 
and Coulbourn, 1982; Andruleit, 1997). Only the species with robust structure (as Calcidiscus spp. and Umbilicosphaera spp.) or high cell densities (such as E. huxleyi) have a higher preservation potential. In the lower photic zone, species such as $F$. profunda have slight advantages because of less destruction by biological breakdown and a shorter transport distance (Andruleit, 1997; Andruleit et al., 2004). As a result, the fossil assemblages cannot precisely represent the living community from which they are derived. However, despite the loss in species diversity of fossil assemblages, the coccolithophore record has a much higher preservation capability than many other proxies (Samtleben et al., 1995; Beaufort et al., 1997; Balch et al., 2000; Andruleit et al., 2004) and therefore is one of the most reliable groups for paleoenvironmental reconstructions.

\section{Conclusions}

An interesting application concerns the use of knowledge from the study of living communities in the explanation and documentation of fossilized records. One important parameter of the ecological research on living coccolithophore communities from the coastal ecosystems of Andros Island lies in the seasonal separation of the subtropical species. This distinction led to the differentiation of coccolithophore communities, as a response to short-time scale seasonal fluctuations in temperature and nutrient content in the upper photic zone. More specifically, a fluctuation of species in eutrophic and oligotrophic environments was observed, in the context of seasonality (cool-warm period), a parameter that cannot be easily specified in fossil assemblages.

The present study identifies four distinct calcareous nannoplankton groups from NS-14 sediment core, suggesting that variability in coccolithophore composition is controlled by changes in temperature, salinity, productivity and nutrient flux in the water column. The paleoecological groups are used as a basis for discussion of the relation of Holocene assemblages with living communities in the coastal marine ecosystems of the Aegean Sea. In the comparison it becomes obvious that the living ecological groups are exclusively correlated with the Holocene paleoecological Group A that indicates a seasonally controlled marine environment. The ample development of Group A before $10 \mathrm{Ka}$ and towards the recent times should mainly be interpreted through the existence of seasonality. So in the particular period, the warm season would be characterized by oligotrophic conditions in the photic zone, with high occurrence of representatives of the Rabdosphaeraceae and Syracosphaeraceae, while water mixture during the cool period allowed the increase of E. huxleyi. However, the wide variety of species composition in living communities is not preserved in the fossil assemblages. This is most probably due to dissolution effects in the water column and the state of preservation in the sediment.

\section{Acknowledgements}

Financial support for this research has been provided by the Research Project 70/4/8644 of the University of Athens and the 01ED100/PENED Project of the European Union, the General Secretariat for Research \&Technology/Greek Ministry of Development and the Municipality of Chora, Andros Island.

\section{References}

Ahagon, N., Tanaka, Y., and Ujiie, H., 1993. Florisphaera profunda, a possible nannoplankton indicator of late Quaternary changes in sea-water turbidity at the northwestern margin of the Pacific. Marine Micropaleontology, 22, 255-273.

Andruleit, H., 1997. Coccolithophore fluxes in the Norwegian-Greenland Sea: seasonality and assem- 
blage alterations. Marine Micropaleontology, 31, 45-64.

Androuleit, H., and Rogalla, U., 2002. Coccolithophores in surface sediments of the Arabian Sea in relation to environmental gradients in surface waters. Marine Geology, 186, 505-526.

Andruleit, H., Rogalla, U., and Stäger, S., 2004. From living communities to fossil assemblages: origin and fate of coccolithophores in the northern Arabian Sea. In Triantaphylou, M. (ed.), Advances in the biology, ecology and taxonomy of extant calcareous nannoplankton. Micropaleontology, 50(supplement 1), 5-21 pp.

Balch, W.M., Drapeau, D.T., and Fritz, J.J., 2000. Monsoonal forcing of calcification in the Arabian Sea. Deep-Sea Research II, 47(7-8), 1301-1337.

Baumann, K.-H., Andruleit, H., Böckel, B., Geisen, M., and Kinkel, H., 2005. The significance of extant coccolithophores as indicators of ocean water masses, surface water temperature, and paleoproductivity: a review. Paläontologische Zeitschrift, 79(1), 93-112.

Baumann, K.-H., Bockel, B., and Frenz, M., 2004. Coccolith contribution in the South Atlantic carbonate sedimentation. In Thierstein, H.R., and J.R. Young (eds), Coccolithophores -From Molecular Processes to the Global Impact. Springer, 367-402 pp.

Beaufort, L., Lancelot, Y., Camberlin, P., Cayre, O., Vincent, E., Bassinot, F., and Labeyrie, L., 1997. Insolation cycles as a major control of Equatorial Indian Ocean Prymary Production. Science, 278, 1451-1454.

Brand, L.E., 1994. Physiological ecology of marine coccolithophores. In Winter, A., and W.G. Siesser (eds), Coccolithophores, Cambridge University Press, 39-49 pp.

Castradori, D., 1993. Calcareous nannofossil and the origin of Eastern Mediterranean sapropels. Paleoceanography, 8, 459-471.

Cros, L., 2001. Planktonic coccolithophores of the NW Mediterranean. Tesi Doctoral, Departament d'Ecologia, Universitat de Barcelona, 181 pp.

Crudeli, D., Young, J.R., Erba, E., Geisen, M., Ziveri, P., De Lange G.J., and Slomp, C.P., 2006. Fossil record of holococcoliths and selected hetero-holococcolith associations from the Mediterranean (Holocene-Late Pleistocene): Evaluation of carbonate diagenesis and palaeoecological-palaeocenographic implications. Palaeogeography, Palaeoclimatology, Palaeoecology, 237, 191-212.

Di Stefano, E., and Incarbona, A., 2004. High resolution paleoenvironmental reconstruction of ODP Hole 963D (Sicily Channel) during the last deglaciation based on calcareous nannofossils. Marine Micropaleontology, 52, 241-254.

Dimiza, M.D., Triantaphyllou, M.V., and Dermitzakis, M.D., 2008a. Seasonality and ecology of living coccolithophores in E. Mediterranean coastal environments (Andros Island, Middle Aegean Sea). Micropaleontology, 54(2), 159-175.

Dimiza, M.D., Triantaphyllou, M.V., and Dermitzakis, M.D., 2008b. Vertical distribution and ecology of living coccolithophores in the marine ecosystems of Andros Island (Middle Aegean Sea) during late summer 2001. Hellenic Journal of Geosciences, 43, 7-20.

Findlay, C.S., and Girandeau, J., 2000. Extant calcareous nannoplankton in the Australian Sector on the Southern Ocean (austral summers 1994 and 1995). Marine Micropaleontology, 40, 417-439.

Flores, J.A., Gersonde, R., and Sierro, F.J., 1999. Pleistocene fluctuations in the Agulhas Current Retroflection based on the calcareous plankton record. Marine Micropaleontology, 37, 1-22.

Flores, J.A., Sierro, F.J., Francés, G., Vázquez, A., and Zamarreňo, I., 1997. The last 100,000 years in the western Mediterranean: sea surface water amd frontal dynamics as revealed by coccolithophores. Marine Micropaleontology, 29, 351-366.

Giraudeau, J., 1992. Distribution of Recent nannofossil beneath the Benguela system: southwest African 
continental margin. Marine Geology, 108, 219-237.

Giraudeau, J., Monteiro, P.M.S., and Nikodemus, K., 1993. Distribution and malformation of living coccolithophores in the northern Benguela upwelling system off Namibia. Marine Micropaleontology, 22, 93-110.

Giunta, S., Negri, A., Morigi, C., Capotondi, L., Combourieu-Nebout, N., Emeis, K.C., Sangiorgi, F., and Vigliotti, L., 2003. Coccolithiphorid ecostratigraphy and multi-proxy paleoceanographic reconstruction in the Southern Adriatic Sea during the last deglacial time (Core AD91-17). Palaeogeography, Palaeoclimatology, Palaeoecology, 190, 39-59.

Haidar, A.T., and Thierstein, H.R., 2001. Coccolithophore dynamics off Bermuda (N. Atlantic). Deep-Sea Research II, 48, 1925-1956.

Hammer, O., Harper, D.A.T., and Ryan, P.D., 2001. PAST- Palaeontological Statistics, software package for education and data analysis, Palaeontologia Electronica.

Hiramatsu, C., and De Deckker, P., 1997. The late Quaternary calcareaus nannoplankton assemblages from three cores from the Tasman Sea. Palaeogeography, Palaeoclimatology, Palaeoecology, 131(3/4), 391-412.

Jordan, R., and Chamberlein, A.H.L., 1997. Biodiversity among haptophyte algae. Biodiversity and Conservation, 6, 131-152.

Jordan, R.W., and Winter, A., 2000 . Living microplankton assemblages off the coast of Puerto Rico during January-May 1995. Marine Micropaleontology, 39, 113-130.

Kleijne, A., 1993. Morphology, Taxonomy and Distribution of Extant Coccolithophorids (Calcareous Nannoplankton), Ph. D. Thesis, Vrije Universiteit, Amsterdam, 320 pp.

Knappertsbusch, M.W., 1993. Geographic distribution of living and Holocene coccolithophores in the Mediterranean Sea. Marine Micropaleontology, 12(1), 71-76.

Magurran, A.E., 1988. Ecological Diversity and its Measurement. Croom Helm, London, 179pp.

Malinverno, E., Ziveri, P., and Corselli, C., 2003. Coccolithophorid distribution in the Ionian Sea and its relationship to eastern Mediterranean circulation during late fall-early winter 1997. Journal Geophysical Research, 108 (9): 8115, 2002JC001346.

Molfino, B., and McIntyre, A., 1990. Processional forcing of nutricline dynamics in the Equatorial Atlantic. Science, 249, 766-769.

Müller, C., 1979. Les nannofossiles calcaires. La Mer Pelagienne, 6(1), 210-220.

Negri, A., and Giunta, S., 2001. Calcareous nannofossil paleoecology in the sapropel S1 of the eastern Ionian sea: paleoceanographic implications. Palaeogeography, Palaeoclimatology, Palaeoecology, 169, 101-112.

Papanikolaou, D., and Nomikou, P., 2001. Tectonic structure and volcanic centres at the eastern edge of the Aegean Volcanic Arc around Nisyros Island. Bulletin of the Geological Society of Greece, 34(1), 289-296.

Principato, M.S., Crudeli, D., Ziveri, P., Slomp, C.P., Corselli, C., Erba, E., and De Lange, G.J., 2006. Phyto- and zooplankton paleofluxes during the deposition of sapropel S1 (eastern Mediterranean): Biogenic carbonate preservation and paleoecological implications. Palaeogeography, Palaeoclimatology, Palaeoecology, 235, 8-27.

Roth, P.H., and Coulbourn, W.T., 1982. Floral and solution patterns of coccoliths in surface sediments of the North Pacific. Marine Micropaleontology, 7, 1-52.

Samtleben, C., Baumann, K.-H., and Schröder-Ritzrau, A., 1995. Distribution, compotition and seasonal variation of coccolithophore communities in the northern North Atlantic. In Flores J.A., and F.J. Sierro (eds), Proceedings of the 5th INA Conference, Universidad de Salamanca, 219-235 pp. 
Shipe, R.F., Passow, U., Brzezinski, M.A., Graham, W.M., Pak, D.K., Siegel, D.A., and Alldredge, A.L., 2002. Effect of the 1997-1998 El Niño on seasonal variations in suspended and sinking particles in the Santa Barbara Basin. Progress In Oceanography, 54, 105-127.

Simpson, E.H., 1949. Measurement of diversity. Nature, 163, 688.

Takahashi, K., and Okada, H., 2000. Environmental control on the biography of modern coccolithophores in the southwestern Indian Ocean offshore of Western Australia. Marine Micropaleontology, 39, 73-86.

Triantaphyllou, M.V., Antonarakou, A., Kouli, K., Dimiza, M., Kontakiotis, G., Papanikolaou, M., Lianou, V., Ziveri, P., Mortyn, G., Lykousis, V., and Dermitzakis, M.D., 2009a. Late Glacial-Holocene ecostratigraphy of the south-eastern Aegean Sea, based on plankton and pollen assemblages. Geo-Marine Letters, 29, 249-267. DOI 10.1007/s00367-009-0139-5

Triantaphyllou, M.V., Antonarakou, A., Kouli, K., Dimiza, M., Kontakiotis, G., Ziveri, P., Mortyn, G., Lykousis, V., and Dermitzakis, M.D., 2007. Plankton ecostratigraphy and pollen assemblage zones over the last 14000 years in se Aegean Sea (core NS-14). Bulletin of the Geological Society of Greece, XL, 209-224.

Triantaphyllou, M.V., Dermitzakis, M.D., and Dimiza, M.D., 2002. Holo- and heterococcolithophorids (calcarereous nannoplankton) in the gulf of Korthi (Andros island, Aegean Sea, Greece) during late summer 2001. Revue de Paleobiologie, 21(1), 353-369.

Triantaphyllou, M.V., Ziveri, P., Gogou, A., Marino, G., Lykousis, V., Bouloubassi, I., Emeis, K.-C., Kouli, K., Dimiza, M., Rosell-Melé, A., Papanikolaou, M., Katsouras, G., and Nunez, N., 2009b. Late Glacial-Holocene climate variability at the south-eastern margin of the Aegean Sea. Marine Geology, 266, 182-197. DOI 10.1016/j.margeo.2009.08.005

Triantaphyllou, M.V., Ziveri, P., and Tselepides, A., 2004. Coccolithophore export production and response to seasonal surface water variability in the oligotrophic Cretan Sea (NE Mediterranean). Micropaleontology, 50, 127-144.

Winter, A., Jordan, R.W., and Roth, P., 1994. Biogeography of living Coccolithophores in oceanic waters. In Winter, A., and W.G. Siesser (eds), Coccolithophores, Cambridge University Press, 13-27 pp.

Young, J.R., 1994. Functions of coccoliths. In Winter, A., and W.G. Siesser (eds), Coccolithophores, Cambridge University Press, 13-27 pp.

Young, J.R., Geisen, M., and Probert, I., 2005. A review of selected aspects of coccolithophore biology with implications for paleobiodiversity estimation. Micropaleontology, 51(4), 267-288.

Ziveri, P., Baumann, K.-H., Böckel, B., Bollmann J., and Young, J.R., 2004. Biogeography of selected Holocene coccoliths in the Atlantic Ocean. In Thierstein, H.R., and J.R. Young (eds), Coccolithophores. From Molecular Processes to Global Impact, Springer, 403-428 pp. 